IJMS 18 (2), 43-66 (2011)

\title{
CUSTOMER LOYALTY: THE CASE OF MOBILE PHONE USERS IN UNIVERSITI UTARA MALAYSIA
}

\author{
MEGUELLATI ACHOUR \\ Institute of Graduate Studies \\ Universiti Malaya \\ NOR PUJAWATI MD. SAID \\ UUM College of Business \\ Universiti Utara Malaysia \\ ALI BOERHANNOEDDIN \\ Faculty of Economics and Administration \\ Universiti Malaya
}

\begin{abstract}
This research attempts to examine the relationships between service quality, switching barriers and brand image and customer loyalty in the Universiti Utara Malaysia sector. Based on the theoretical model, a comprehensive set of hypotheses were formulated and a methodology for testing them was outlined. These hypotheses were tested empirically by means of questionnaires to demonstrate the applicability of the theoretical model. The results indicate that service quality, switching barriers, and brand image are separate constructs that combine to determine loyalty, with service quality and switching barriers exerting a stronger influence than brand image. Hypotheses H1, H2 were supported, while hypothesis $\mathrm{H} 3$ was rejected.
\end{abstract}

Keywords: Customer loyalty, brand image, switching barriers, service quality.

\section{Introduction}

Customer loyalty has become more important as technology is undergoing rapid changes in the telecommunications sector. Customers know what is available elsewhere, and at other locations, and may be willing to travel farther for a bargain. A critical issue for the continued success of an organization is its capability to retain its current customers and make them loyal to its brands (Dekimpe, Steenkamp, Mellens \& Abeele, 1997). Loyal customers build 
businesses by buying more, paying premium prices, and providing new referrals through positive words over time (Ganesh, Arnold \& Reynolds, 2000). Loyalty research in services is an important area to study (Gremler, 1995). In fact, in telecommunications companies 2-4 per cent of their customers are lost monthly; disloyal customers can amount to millions of lost revenue and profit. In telecommunications services, it is frequently pointed out that once customers have been acquired and connected to the telecommunications network of a particular operator; their long-term relations with the focal operator are of greater importance to the success of the company in competitive markets than they are in other industry sectors (Gerpott, Rams \& Shindler, 2001).

In the case of Malaysia, numerous studies have been carried out with regards to customer loyalty in several services sectors. According to Nilson (2007) on a sample of 220 bank customers in Malaysia, multiple regression analysis assessed the impact of customer loyalty on four key constructs of marketing relationship (trust, commitment, communication and conflict handling). The findings of the study show that the four variables possess a significant effect and are able to predict a good proportion of the variance in customer loyalty. Moreover, they are significantly related to each other. Chang and Ernest's, Satisfaction and loyalty: Customer Perceptions of Malaysian Telecommunication Service Providers (2009) - was done by utilizing a two-part research method. The first part utilized an in-depth interview method to obtain the variables used in the second part of the study. The second part consisted of a questionnaire distributed to 125 respondents. A factor analysis was also carried out. The findings indicated that important variables for satisfaction included supporting services, products (handiness, reliable coverage, friend, and family lines) and promotional efforts of the firm; while for loyalty, they refer to convenience, services, satisfaction and cost.

The findings suggest that telecommunication service providers should look beyond price wars to keep their customers satisfied and loyal. As market growth slows or as markets become more competitive, firms are more likely to attempt to maintain their market share by focusing on retaining current customers. In this context, the main objective of this research is to examine the relationships between customer loyalty and service quality, switching barriers and brand image in Universiti Utara Malaysia. For this purpose, there are three specific objectives of this research:

(a) To examine the relationship between service quality and customer loyalty,

44 IJMS 18 (2), 43-66 (2011) 
(b) To determine the relationship between switching barriers and customer loyalty, and

(c) To determine the relationship between brand image and customer loyalty. This research attempts to answer the following questions:

- Is there any relationship between service quality and customer loyalty?

- Is there any relationship between switching barriers and customer loyalty?

- Is there any relationship between brand image and customer loyalty?

With the description of the research already introduced, the literature review will focus on discussions and ideas in previous studies related to customer loyalty and the factors affecting it. There are several definitions of customer loyalty. Customer loyalty is defined as a customer who repurchases from the same service provider whenever possible, and who continues to recommend or maintain a positive attitude towards the service provider (Bloemer, Ruyter \& Wetzels, 1999; Gremler \& Brown, 1999; Shoemaker \& Lewis; 1999, Kandampully \& Suhartanto, 2000). According to Wong and Sohal (2003a) customer loyalty appears to consist of three separate dimensions, namely; the behavioural, attitudinal and cognitive dimensions. Customer loyalty has been generally described as occurring when customers:

- $\quad$ Repeatedly purchase goods or services over time.

- Hold favourable attitudes towards goods or services, or towards the company supplying the goods or services (Wong \& Sohal, 2003b).

It should be noted however, that customer loyalty has been studied for several decades by marketers, but it is not a well understood phenomenon (Gremler, 1995). Furthermore, there is no consensus on the most appropriate way to measure loyalty.

There are three groups of studies that reflect both the major approaches to defining and/or measuring customer loyalty and the limitation of these approaches. The three groups are:

(a) Loyalty as repeated purchase behaviour (e.g., Liljander \& Strandvik, 1993),

(b) A composite approach of repeat patronage combined with an attitudinal component (e.g, Dick \& Basu, 1994), and

(c) a psychological state of loyalty (e.g, Czepiel, 1990a). 
The first approach is to treat loyalty as either an actual purchase behaviour or as repeat purchase intentions. This approach has long been criticized for leading to spurious loyalty (Day, 1969), while the composite approach lacks theory (Jacoby \& Chestnut, 1978). Customers may be loyal due to high switching barriers or lack of real alternatives. Customers may also be loyal because they are satisfied and thus want to continue the relationship.

History has proven that most barriers to exit are limited with regard to durability; companies tend to consider customer satisfaction as the only viable strategy in order to keep existing customers. Several authors have found a positive correlation between customer satisfaction and loyalty (Bearden, Teel et al., 1980; Bolton \& Drew, 1991; Fornell, 1992; Anderson \& Sullivan, 1993). Customer loyalty is a buyer's overall attachment or deep commitment to a product, service, brand, or organization (Oliver, 1999). Customer loyalty falls into two broad categories: The behavioural and the attitudinal. As a behaviour, customer loyalty has been measured as the long-term choice probability for a brand, including hardcore, loyalty and repeat purchase probability. Attitudinal approaches focused mainly on brand recommendations, resistance to superior products, repurchase intention, and willingness to pay a premium price.

Oliver (1999) defines loyalty as a deeply-held commitment to re-buy products/services consistently in the future, thereby causing repetitive same brand or same-brand set purchasing. The customer's attitude toward a service or product (brand) including attitudinal preference and commitment has a greater impact on forming loyalty. Goodwin and Gremler (1996) cite quality in the relationship as a necessary element in defining loyalty. Earlier studies of factors affecting customer loyalty usually set the focus on customer satisfaction and the switching barrier (e.g., Dick \& Basu, 1994; Gerpott, Rams \& Schindler, 2001; Lee \& Cunningham, 2001). Customers experiencing a high level of satisfaction are likely to remain with their existing providers and maintain their subscription. However, according to some research, customer satisfaction, while positively influencing customer loyalty, is not always a sufficient condition, and, in some cases, fails to produce the expected effect. Hence, these researchers suggest that it is necessary to analyse other potentially influential factors.

It is in this context that the concept of the switching barrier was proposed (Jones, Mothersbaugh \& Betty, 2002). From previous studies about customer loyalty and the factors affecting it such as service quality, switching barriers, and brand image, researchers gave different definitions of customer loyalty. However, there were some 
things that were similar among their definitions, such as repeatedly purchased goods or services over time; and holding favourable attitudes towards a good or service, or towards the company supplying the goods or service. The differences between their definitions are the factors affecting customer loyalty, for example the factors affecting loyalty to cars is much different from the factors affecting loyalty to mobile phones or any product that is consumed daily, monthly or yearly, as mentioned by Jun and Bin (2005).

\section{Factors Affecting Customer Loyalty}

Customer loyalty is characterized by repurchasing and not by transferring the product/service through market fluctuation. There are many factors that affect customer loyalty. In the telecommunication industry, according to the opinions of experts and the literature on previous studies, the effects of customer loyalty can be assessed in these aspects: service quality, switching barriers, and brand image "the customers' switching cost requirement, quality requirement and service requirement for the telecommunication business" (Zhijian, Xu $\& \mathrm{Li}, 2005)$.

\section{Service Quality and Customer Loyalty}

Service quality in the telecommunications industry is an important indicator to assess a company's performance. Service quality in telecommunications has mainly been researched on technical and/ or corporate strategies (Douligeris \& Pereira, 1994; Gruber, Abdou, Richards \& Williams, 1986; Jung, 1996a, 1996b; Lim, Widdows \& Park, 2006; Lynch, Buzas \& Berg, 1994; Takahashi, 1988). Due to the inherent intangibility, inseparability, heterogeneity and perishability of characters, service quality can be defined as a consumer's overall impression of the relative efficiency of the organization and its services. The dominant conceptualization and measurement of service quality has been the SERVQUAL instrument developed by Parasuman et al., 1988). SERVQUAL identified the determinants of perceived quality and indicated through arithmetic the differences between customer expectations and perceptions across 22 measurement items.

Using factor analysis, SERVQUAL is further condensed into tangible, reliability, assurance and empathy dimensions, which are generic across service sectors. However, a number of authors investigated the number of dimensions and the stability of the items across different industries through empirical tests-and concluded that the five component factor structure was not confirmed in any of the research 
samples. This implies that service quality attributes are contextdependent and should be selected to reflect the service environment investigated. Cronin et al. $(1992,2002)$ criticized SERVQUAL's poor reliability and argued that expectation is neither sufficient nor a necessary condition, and therefore identified a performance-only measurement, called the SERVPERF instrument. The results of existing studies on service quality suggest that definitions of service quality in mobile telecommunication settings are quite diverse, and do not seem to fit any single existing quality model. In this study, for the sake of brevity, the modified SERVPERF instrument has been adapted for the mobile telecom industry (Zhijian, Xu \& Li, 2005).

\section{Switching Barriers and Customer Loyalty}

The switching barrier refers to the difficulty of switching to another provider that is encountered by a customer who is dissatisfied with the existing service, or to the financial, social and psychological burden felt by a customer when switching to a new carrier (Fornell, 1992). Therefore, the higher the switching barrier, the more a customer is forced to remain with his or her existing carrier. According to a previous study, the switching barrier is made up of the switching cost, the attractiveness of the alternatives, and interpersonal relationships $\left.{ }^{*}\right)$. Switching cost means the cost incurred when switching, including time, money and psychological cost. Jackson (1985) categorized switching costs as psychological, physical, and economic in nature. In addition to objectively measurable monetary costs, switching costs may also pertain to the time and psychological effort involved in facing the uncertainties of dealing with a new service provider.

According to Burnham's (1998) review and typology, switching costs were broadly grouped into three categories: procedural, financial and relational, Attractiveness of the alternatives means the reputation, image and service quality of the replacing carrier, which are expected to be superior or more suitable than those of the existing carrier. Interpersonal relationship means a psychological and social relationship that manifests itself as care, trust, intimacy and communication. Switching barriers lock customers in their initial decisions, which hand market power to the service supplier. Thus, suppliers can hinder customers from switching to their rivals for a relatively low price and can segment and discriminate their customers with varying levels of willingness to pay. No matter how, suppliers can exploit their customers.

Switching costs are partly consumer-specific (Shy, 2002). For this reason, a switching cost can be seen as a cost that deters customers from demanding a rival firm's brand. The economic or financial 
switching cost is a sunk cost which appears when the customer changes his/her brand, for example the costs of closing an account with one bank and opening another with a competitor, and the cost of changing one's long-distance telephone service (Klemperer, 1987) or the costs of changing one's GSM operator.

\section{Brand Image and Customer Loyalty}

Oliver (1999) proposes that eventual customer loyalty is a role of perceived product superiority, personal fortitude, social bonding, and their respective synergistic effects. Further analysis of Oliver's discussion tends to suggest that loyalty is not commitment, but rather that loyalty is an aspect of commitment labeled as an attitudinal or emotional component of commitment (Meyer \& Allen, 1991, 1997; Meyer et al., 1993; Ogba, 2008). A brand's image often influences a customer's expectations and consequently his/her satisfaction with a product or service. Brand image pertains to the perception or the mental picture a customer holds of a brand and is formed through his/her response, whether reasoned or emotional; an organization's image, on the other hand, is an important variable that positively influences marketing activities. Image is considered to have the ability to influence customers' perceptions of the goods and the services offered (Zeithaml \& Bitner, 1996). Thus, image will have an impact on the customers' buying behaviour. The objective is to arouse a positive affective response to the brand in the customers, such that they buy brands for their physical attributes and functions, and the symbolic meanings associated with the brand, product or service. During its formation, the customer's experiences, feelings and trust will influence the image. Nguyen and Leblanc (2001) claim that corporate image is related to the physical and behavioural attributes of the firm, such as business name, architecture, variety of products/services, and to the impression of quality communicated by each person interacting with the firm's clients.

From marketing literature regarding goods we have learned that brand reputation has been defined as a perception of quality associated with the name (Aaker \& Keller, 1990). Corporate image in service-marketing literature was identified as an important factor in the overall evaluation of the service and the company (Grönroos, 1984); (Gummesson \& Grönroos, 1988); (Bitner, 1991). Apart from image as a function of the accumulation of purchasing/consumption experience over time, most organizations also provide complex and noisy informational environments (e.g. advertising, direct marketing, or PR) in order to attract new customers and keep the existing ones. In 
the Perceived Quality Model (Grönroos, 1988) perceived quality is a function of expected quality (generated from market communication, image, word-of-mouth, and customer needs) and experienced quality (generated from technical quality and functional quality). Mobile telecommunications markets can be divided by the type of services provided and by the telecommunications network used (Gerpott et al., 2001).

\section{Hypotheses and Structural Model}

H1: Service quality has a positive relationship with customer loyalty. H2: Switching barriers has a positive relationship with customer loyalty.

H3: Brand image has a positive relationship with customer loyalty.

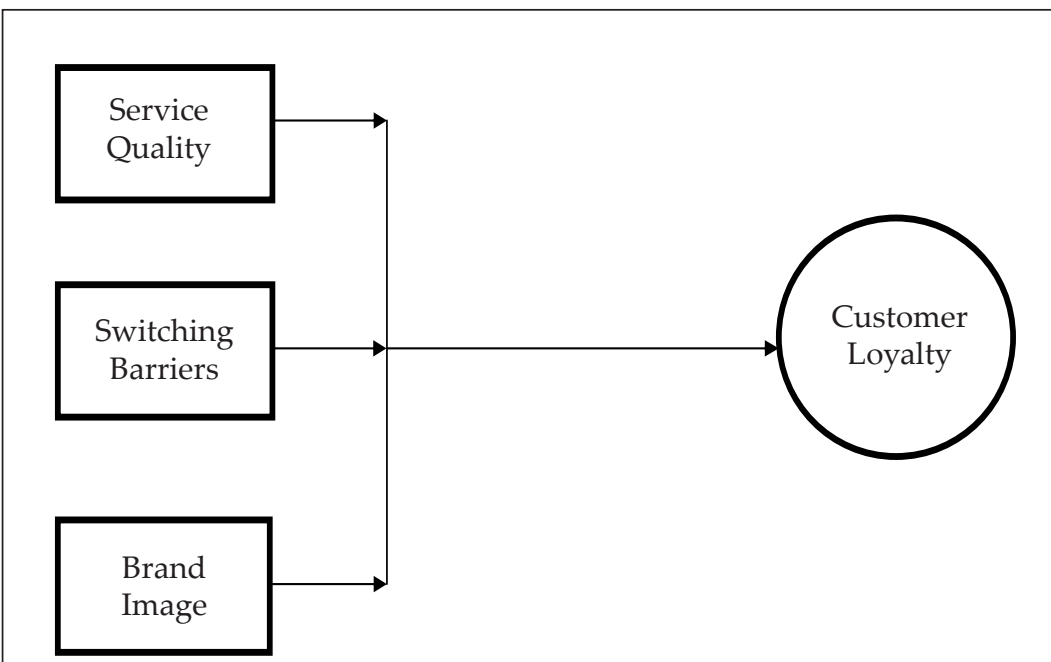

Figure 1. Theoretical framework of the relationship between service quality, switching barriers, and brand image and customer loyalty.

\section{Methodology}

This study involved a survey of the users of a mobile phone service in Universiti Utara Malaysia. The methodology was comprised of a research design, population; sample size, questionnaire design,

50 IJMS 18 (2), 43-66 (2011) 
analysis, result of reliability and procedure. There are two types of customer loyalty-for company and for product. This research focused on customer loyalty for product, and also on three factors namely, service quality, switching barriers, and brand image. Thus, three hypotheses were considered to determine the relationship between those factors and customer loyalty. Furthermore, customer loyalty was the dependent variable, and other factors were the independent variables.

The population of this research was composed of the staff and student users of mobile phones in Universiti Utara Malaysia (UUM). The population size was 28,790 users. Based on Sekaran (1992), the sample size of this research, was 378 users. The convenience sampling method was used. Convenience samples are the most common form of sampling designs in social science research (Mohr, 1990) and provide researchers with an acceptable database to use statistical inference techniques. This approach to sampling design is also common in services marketing. The questionnaires were distributed at the library and the Student's Affairs Department where students would gather in the foyer between classes.

There were two main sections in the questionnaires. The first section was the demographic characteristics of the respondents. These characteristics were: age group, gender, education, marital status, and career. The second section of the questionnaire was pertaining to the dependent variable-customer loyalty, and the three independent variables-service quality, switching barriers and brand image. There were thirty-five questions in this section, eight questions for customer loyalty, eleven questions for service quality, eight questions for switching barriers, and eight questions for brand image. Measures for independent and dependent variables used a five-point Likerttype response format, with "strongly disagree" and "strongly agree". The users recorded their assessment of the items on five-point Likerttype scales ( $1=$ strongly disagree, $2=$ disagree, $3=$ neutral, $4=$ agree, $5=$ sThe questionnaires were pretested with twenty users of mobile phones consisting of staff and students at Universiti Utara Malaysia. The purpose of the research was explained to the users of mobile phones in an effort to facilitate the users' feedback, suggestions, and answering of the questions. The users suggested that some words in the questions were not clear or straight forward. Except for these comments, the results of the pretest indicated that, on an overall level, the questions were realistic, clear, and easy to follow. Following the pretest, the unclear words and sentences were revised.

IJMS 18 (2), 43-66 (2011) 5 
The descriptive analysis and correlation of the variables customer loyalty, service quality, switching barriers, and brand image in this research used three hypotheses to assess the relationship between the independent variables and the dependent variables. This research described the degree of the relationship between all the independent variables and the dependent variables. Regression analysis was also used for the investigation of the relationships between the variables.

\section{Reliability Results}

The result of the reliability test is as per table below:

Table 1

Reliability Results

\begin{tabular}{lcc}
\hline Variables & Number of items & Alpha \\
\hline Independent Variables & & \\
- Service quality & 11 & .785 \\
- Switching barriers & 8 & .757 \\
Brand image & 8 & .810 \\
Dependent Variable & & \\
- $\quad$ Customer loyalty & 8 & .778 \\
\hline
\end{tabular}

The reliability test was conducted using the Coefficient Cronbach's Alpha which is a measure of reliability or internal consistency. A value of Cronbach's Alpha of .50 or above is consistent with the recommended minimum values as stated by Nunnally (1967). Cronbach's Alpha indicated the reliability for each factor as follows: customer loyalty .778, service quality .785, switching barriers .757, brand image .810 . Therefore, the research results can be accepted as stated by Nunnally (1978).

\section{Findings}

\section{Demographic Variables}

The respondents were male $(43.30 \%)$ and female $(56.7 \%)$. Their ages ranged from $18-25$ years $(84.0 \%)$, $26-35$ years $(10.0 \%)$, 36-45 years $(4.0 \%)$, and others $(0.7 \%)$. Their marital status was single $(84.7 \%)$

52 IJMS 18 (2), 43-66 (2011) 
and married (15.3\%). The following were the education level of the respondents; those with high school certificates $(24.7 \%)$, diplomas $(9.3 \%)$, degrees $(54.7 \%)$, and postgraduate degrees $(10.7 \%)$.

The sample consisted of students $(87.3 \%)$, staff $(12.0 \%)$ and lecturers $(0.7 \%)$. All the results are shown in the table below:

Table 2

Demographic Results

\begin{tabular}{llcc}
\hline & & Frequency & Percentage (\%) \\
\hline Age & $18-28$ & 126 & 84 \\
& $26-35$ & 15 & 10 \\
\multirow{5}{*}{ Gender } & $36-45$ & 6 & 4 \\
& 46 and over & 3 & 2 \\
Education level & Female & 85 & 56.7 \\
& Male & 65 & 43.3 \\
& High School & 37 & 24.7 \\
& Diploma & 14 & 9.3 \\
Marital status & Degree & 83 & 55.3 \\
& Postgraduate & 16 & 10.7 \\
Career & Single & 127 & 84.7 \\
& Married & 23 & 15.3 \\
& Student & 131 & 87.3 \\
& Staff & 18 & 12.0 \\
& Lecturer & 1 & 0.7 \\
\hline
\end{tabular}

\section{Correlation Analysis}

Table 3

Correlation Matrix

\begin{tabular}{lcccc}
\hline Variables & $\begin{array}{c}\text { Customer } \\
\text { loyalty }\end{array}$ & $\begin{array}{c}\text { Service } \\
\text { quality }\end{array}$ & $\begin{array}{c}\text { Switching } \\
\text { barriers }\end{array}$ & $\begin{array}{c}\text { Brand } \\
\text { image }\end{array}$ \\
\hline Customer loyalty & 1 & & & \\
Service quality & $.561^{* *}$ & 1 & & \\
Switching barriers & $.516^{* *}$ & $.718^{* *}$ & 1 & \\
Brand image & $.382^{* *}$ & $.610^{* *}$ & $.599^{* *}$ & 1 \\
\hline
\end{tabular}

IJMS 18 (2), 43-66 (2011) 53 
Table 3 exhibits the correlation coefficients between all variables. All independent variables are correlated significantly with customer loyalty. The correlation is significant at the 0.01 level (2-tailed). The criterion used for the level of significance was set a priori. The relationship must be at least significant at ${ }^{* *} p<0.01$. Table 3 shows that there is significant correlation between customer loyalty and service quality, $(\mathrm{r}=0.561, \mathrm{p}=0.000<0.01)$, a strong positive significant correlation between customer loyalty and switching barriers, $(\mathrm{r}=0.516$, $\mathrm{p}=0.000<0.01$ ). Therefore, it can be said that there is a strong positive significant correlation between customer loyalty and switching. Also, there is a significant correlation between customer loyalty and brand image, $(r=0.382, p=0.000<0.01)$. This shows that there is a moderate positive significant correlation between customer loyalty and brand image.

\section{Regression Analysis}

The linear regression procedure examines the relationship between a dependent variable and a set of independent variables. This research also analysed the relationship between customer loyalty and service quality, switching barriers, and brand image using regression analysis, and the results are as shown in Table 4 .

Table 4

Regression Matrix

\begin{tabular}{lcc}
\hline Independent Variables & $\mathrm{B}(\mathrm{t}-\mathrm{value})$ & sig \\
\hline Service quality & 0.396 & 0.000 \\
& $(3.843)$ & \\
Switching barriers & 0.232 & 0.023 \\
& $(2.301)$ & \\
Brand image & 0.004 & 0.965 \\
& $(0.044)$ & \\
R Square & 0.341 & \\
Adjusted R Square & 0.327 & \\
\hline
\end{tabular}

As expected, the results of all the independent variables are positively correlated with customer loyalty. However, the correlation on brand image is not statistically significant. This implies that customer loyalty and brand image are unrelated. But the correlation on service quality and switching barriers are statistically significant. This means that

54 IJMS 18 (2), 43-66 (2011) 
customer loyalty, service quality and switching barriers are related. The research investigated the influence of service quality, switching barriers, and brand image. As expected, service quality $(\beta=0.392$, $\mathrm{t}$-value $=3.843, \mathrm{p}<0.01)$ and switching barriers $(\beta=0.232$, $\mathrm{t}$-value $=$ $2.301, \mathrm{p}<0.001$ ) had a significant and strong positive influence on customer loyalty. However, brand image had no significant influence on customer loyalty $(\beta=0.004, t$-value $=0.044, p=0.965)$ at the 0.05 level. Thus, hypotheses $\mathrm{H} 1, \mathrm{H} 2$ were supported, while hypothesis $\mathrm{H} 3$ was rejected. The research found that the proposed model explained a significant percentage of variance in loyalty ( $\mathrm{R}$ Square $=34 \%$ ).

\section{Discussion}

In hypotheses $\mathrm{H} 1, \mathrm{H} 2$, and $\mathrm{H} 3$ the research investigated the influence of service quality, switching barriers, and brand image on customer loyalty. The Pearson coefficient for the relationship between customer loyalty and service quality is .561, so there is a moderate and positive relationship between customer loyalty and service quality. The finding is supported by Huan et al. (2005) and Aydin and Ozer (2004); the hypothesis (H1) is accepted. Service quality also has a significant impact on customer loyalty in what appears to be call quality, valueadded services, and customer support. This suggests that, while mobile carriers have improved call quality over the past several years through massive equipment investments, call clarity and coverage, according to customers' perceptions, still remain important. In addition, mobile carriers must concentrate their efforts on developing value-added services to increase enjoyment and convenience. In the area of customer support, carriers must strive to minimize customer inconvenience by speedily processing customers' complaints through a variety of systems and channels.

The Pearson coefficient for the relationship between customer loyalty and switching barriers is .516. Thus there is a moderate and positive relationship between customer loyalty and switching barriers. As a result, switching barriers are positively related to customer loyalty. Switching barriers are positively and significantly related to customer loyalty $(p=0.023<0.01)$ and based on the results of previous studies by Huan et al. (2005) and Aydin. S and Ozer. G (2004) the hypothesis (H2) is accepted and supported. Switching barriers have significant impact on customer loyalty which appeared to be switching costs such as loss cost, move-in cost, and interpersonal relationships. Carriers must continuously develop customer-reward programmes that concretely compensate customers, such as mileage programmes

IJMS 18 (2), 43-66 (2011) 55 
and price discounts, in order to increase loss cost and move-in cost. Furthermore, interpersonal relationships between carrier and customer are factors that retain customers, even when competitors try to win them over with lower prices or offers of other conveniences.

The Pearson coefficient for the relationship between customer loyalty and brand image is .382, and therefore, there is a relationship between customer loyalty and brand image, although it is low and positive. Regardless of the weakness of the correlation, it still shows a positive relationship between customer loyalty and brand image. Brand image is not statistically significant. $(p=0.965>0.01)$ and based on the results of previous studies by Aydin and Ozer, (2004) hypothesis (H3) is rejected. Although it is not significant, the analysis results indicate that corporate image affects customer loyalty positively. The general experience of marketing professionals also verifies that such an effect is valid. The situation can be explained by the general characteristics of the Malaysian mobile phone market, since the purchasing power of subscribers is less than in developed countries, and the indirect tax rate in the brands sector is relatively higher in Malaysia. Consequently, the most important factor for the decisionmaking process of subscribers is the services provided by the operator compared to cost. The operator's image has no significant effect on customer loyalty in the Malaysia brands sector.

\section{Recommendation}

Several new ideas arose while pursuing this research which led to the following recommendations. Service quality and switching barriers are two important routes to customer loyalty for most service companies, either in retaining or attracting customers. Research related to the importance of service quality and switching barriers in attracting new customers to the company and how this may change between different service industries is in dire need. In the emerging paradigm of relationship marketing, there is a need to understand the importance of service quality and switching barriers in retaining customers. This research focused on the impact of brand image, switching barriers, and service quality on customer loyalty. One problem of estimating the existing customers' experience with the company and their perception of it is the closeness of the two constructs. This may create a validity problem. Research related to construct, i.e., finding good measures of service quality, brand image, switching barriers and loyalty, is therefore required. This research covered $34 \%$ of the areas of the factors affecting customer loyalty, so there emerged a number of some recommendations and advice:

56 IJMS 18 (2), 43-66 (2011) 
- To employ other variables such as commitment, satisfaction, and trust as factors affecting customer loyalty.

- To replicate the investigation, to explain other regions or countries in order to obtain a broader view and analysis.

- Conduct an in-depth research about the profitability of loyal customers in comparison to the costs of retaining them.

- Explore if responsiveness to the marketing efforts really have an effect on the customers' buying behaviour.

\section{Conclusion}

In this research, the relationships between customer loyalty and service quality, switching barriers and brand image are examined. To this end, the data was analysed by correlation and regression analysis. The results of the regression analysis show that all the factors have positive effects on customer loyalty. For example, the effect of service quality on customer loyalty stems from positive relations between service quality and factors such as brand images and switching barriers. Although it is not significant, the analysis results indicate that brand image positively affects customer loyalty. The general experience of marketing professionals also verifies that such an effect is valid. The situation can be explained by the general characteristics of the Malaysian mobile phone market, as the purchasing power of the subscribers in Malaysia is less than those in developed countries.

Customer loyalty is a dependent variable in regression analysis. The objective of regression analysis was to determine which of the three factors would have the most important influence on customer loyalty. Of the three relations which were hypothesized to influence customer loyalty; service quality and switching barriers were significantly and positively related, while brand image was not significant.

The Pearson coefficient for the positive relationship between customer loyalty and service quality is .561. This tells us that, just as predicted, as service quality increases, customer loyalty increases. The Pearson coefficient for the positive relationship between customer loyalty and switching barriers is .516. Therefore, as switching barriers increase, customer loyalty increases. In conclusion, service quality and switching barriers are important predictors of customer loyalty. These findings indicate that switching barriers and, to a lesser extent, service quality are crucial factors for customer loyalty rather than brand image. Generally, as discussed above, the findings show that service quality is a necessary but insufficient condition for customer 
loyalty to emerge and to exist. In addition, consistent with previous research, brand image, service quality and especially switching barriers should be taken into consideration in formulating strategies for developing customer loyalty.

\section{End Note}

$\left(^{*} \quad\right.$ While prepaid cards influence customers to churn in some major countries, the situation differs in Korea where prepaid card usage for mobile telecommunication service is less popular, with only a small proportion of users, including foreigners.

\section{References}

Aaker, D., \& Keller, K. L. (1990). Consumer evaluations of brand extentions. Journal of Marketing, 54(1), 27-41.

Aaker, D. A. (1991). Managing brand equity. New York: The Free Press.

Andreassen, T. W., \& Bredal, D. (1996). Kundepleie i praksis. Relasjonsmarkedsføring på for brukermarkedet, AdNotam Gyldendal Forlag as, Oslo.

Andreassen, T. W. (1995). Small, high cost countries strategy for attracting $\mathrm{MNC}^{\prime} \mathrm{s}$ global investments. The International Journal of Public Sector Management, 8(3).

Anderson, E. W. (1998). Customer satisfaction and word of mouth. Journal of Service Research, 1(1), 5-17.

Annie, H. Liu., Mark, P. L., \& Kenneth, L. B. (2005). Examining customer value perceptions of organizational buyers when sourcing from multiple vendors. Journal of Business Research, $58,59-58$.

Asuncion, B., Josefa, D. M., \& Augustin, Q. (2004). A model of customer loyalty in the retail banking market. European Journal of Marketing, 38(1/2), 253-275.

Aydin, S., \& Ozer, G. (2004). The analysis of antecedents of customer loyalty in the Turkish mobile telecommunication market. European Journal of Marketing, 39(7/8), 910-925.

Bagozzi, R. P., \& Yi, Y. (1988). On the evaluation of structural equation models. Journal of the Academy of Marketing Science, 16(Spring), 77-94.

Barber, F., \& Campbell, J. D. (2001). Layoffs: Creating or destroying shareholder value? Ivey Business Journal, 66(1), 13.

Bearden, W., J. Teel, et al. (1980). A path model of consumer complaint behavior. Marketing in the 80s'. The International Journal of Public Sector Management, 10(8).

58 IJMS 18 (2), 43-66 (2011) 
Bell, S. J., Auh, S., \& Smalley, K. (2005). Customer relationship dynamics: Service quality and customer loyalty in the context of varying levels of customer expertise and switching costs customer relationship. Journal of the Academy of Marketing Science, 33, 169.

Bendapudi, N., \& Berry, L. L. (1997). Customers' motivations for maintaining relationships with service providers. Journal of Retailing, 73(1), 15-37.

Benjamin, O. E. (2006). Correlates of customer loyalty to their bank: A case study in Nigeria. International Journal of Bank Marketing, 24(7), 494-508.

Bennett, R., \& Gabriel, H. (2001). Reputation, trust and supplier commitment: The case of shipping organization/seaport relations. The Journal of Business \& Industrial Marketing, 16(6/7), 424-438.

Bentler, P. M., \& Bonett, D. G. (1990). Comparative fit indices in structural models. Psychological Bulletin, 107(2), 238-46.

Bloemer, J., Ruyter, K., \& Wetzels, M. (1998). On the relationship between perceived service quality, service loyalty and switching costs. International Journal of Industry Management, 9(5), 436-53.

Bloemer, J., de Ruyter, K., \& Wetzels, M. (1999), Linking perceived service quality and service loyalty: A multi-dimensional perspectives. Journal of Marketing, 33(4), 1082-106.

Cerpoit, T., Rams, W., \& Schindler, A. (2001). Customer retention: Loyalty and satisfaction in the German mobile cellular telecommunications market. Telecommunication Policy, 25(4), 249-269.

Chang, E. L., \& Ernest. (2009). Satisfaction and loyalty: Customer perceptions of Malaysian telecommunication service providers. Social Science Research Network, 7, 6-18.

Chaudhuri, A., \& Holbrook, M. B. (2001). The chain effects from brand trust and brand affect to brand performance: The role of brand loyalty. Journal of Marketing, 65(April), 31-93.

Christensen, L. T., \& Askegaard, S. (2001). Corporate identity and corporate image revisited - A semiotic perspective. European Journal of Marketing, 35(3/4), 292-31.

Churchill, G. A., \& Suprenant, C. (1982). An investigation into the determinants of customer satisfaction. Journal of Marketing Research, 19(November), 491-504.

Cronin, J. J., \& Taylor, S. A. (1992). SERVPERF versus SERVQUAL: Reconciling performance based and perceptions minus-expectations measurement of service quality. J Mark 358, 125-3.

Czepiel, J. A. (1990). Service encounters and service relationships: Implications for research. Journal of Business Research, 20 (January), 13-21. 
Day, G. (1969). A two-dimensional concept of brand loyalty. Journal of Advertising Research, 9(3), 29-35.

Dekimpe, M. G., Steenkamp, J. B. E. M., Mellens, M., \& Abeele, P. V. (1997). Decline and variability in brand loyalty. International Journal of Research in Marketing, 14, 405-20.

DeWulf, K., \& Odeberken-Schro"der, G. (2003). Assesing the impact of a retailer's relationship efforts on consumers' attitudes and behavior. Journal of Retailing and Consumer Services, 10, 95-108.

Dick, A. S., \& Basu, K. (1994). Customer loyalty: Toward an integrated conceptual framework. Journal of the Academy of Marketing Science, 22, 99-113.

Douligeris, C., \& Pereira, I. J. (1994). A telecommunications quality study using the analytic hierarchy process. IEEE Journal on Selected Areas in Communications, 12(2), 241-250.

Edgett, S., \& Snow, K. (1997). Benchmarking measures of customer satisfaction, quality and performance for new financial service products. Journal of Product and Brand Management, 6(4), 250-259.

Erdem, T., Louviere, J., \& Swait, J. (2002). The impact of brand credibility on consumer price sensitivity. International Journal of Research in Marketing, 19, 1-19.

Ettorre, B. (1996). The care and feeding of a corporate reputation. Management Review, 85(6), 39-43.

Finn. A., \& Kayande, U. (1998). The service quality measurement literature: A generalizability perspective. In T. A. Swartz, D. E. Bowen, \& S. W. Brown (Eds.), Advances in services marketing and management (pp. 97-130) Greenwich, CT: 3M Press.

Fornell, C. (1992). A national customer satisfaction barometer: The Swedish experience. Journal of Marketing, 56(1), 6-21.

Fournier, S., \& Yao, J. L. (1997). Reviving brand loyalty: A conceptualization within the framework of consumer-brand relationships. International Journal of Research in Marketing, 14(5), 451-72.

Ganesan, S. (1994). Determinants of long-term orientation in buyerseller relationships. Journal of Marketing, 58(April), 1-19.

Ganesh, J., Arnold, M. J., \& Reynolds, K. E. (2000). Understanding the customer base of service providers: An examination of the differences between switchers and stayers. Journal of Marketing, 64(July), 65-87.

Gerpott, T. J., Rams, W., \& Schindler, A. (2001). Customer retention, loyalty and satisfaction in the German mobile cellular telecommunications market. Telecommunications Policy, 25, 249-69.

Goodwin, C., \& Gremler, D. D. (1996). Friendship over the counter: How social aspects of the service encounters influence consumer service loyalty. Advances in Services Marketing and Management, 5, 247-282.

60 IJMS 18 (2), 43-66 (2011) 
Gremler, D. D., \& Brown, S. W. (1996). Service loyalty: A global perspective. International Service Quality Association, 171-180.

Gremler, D. D. (1995). The effect of satisfaction, switching costs, and interpersonal bonds on service loyalty. (Unpublished doctoral dissertation). Arizona State University.

Haemoon, Oh. (1999). Service quality, customer satisfaction, and customer value. A holistic perspective hospitality management, 18, 67-82.

Hanson, D., \& Stuart, H. (2001). Failing the reputation management test: The case of BHP. The Big Australian Corporate Reputation Review, 4(2), 128-143.

Heide, Jan. B., \& Allen, M. W. (1995). Vendor consideration and switching behavior for buyers in high-technology markets. Journal of Marketing, 59(July), 30-43.

Hennig-Thurau, T., \& Klee, A. (1997). The impact of customer satisfaction and relationship quality on customer retention: A critical reassessment and model development. Psychology and Marketing, 14(8), 737-764.

Harris, F., \& De Chernatony, L. (2001). Corporate branding and corporate brand performance. European Journal of Marketing, $35(3 / 4), 441-456$.

Heskett, J. L., Thomas, O., Jones, Gary, W. Loveman, EarlW. Sasser., \& Leonard A. Schlesinger. (1994). Putting the service-profit chain to work. Harvard Business Review, 72(2), 164-174.

Hirschman, A. O. (1970). Exit, voice, and loyalty: Responses to decline in firms, organizations, and states. Cambridge, Harvard University Press.

Huan, J., Bandyopadhyay, D., Wang, W., Snoeyink, J., Prins, J., Tropsha, A. (2005). Comparing graph representations of protein structure for mining family-specific residue-based packing motifs. J. Comput. Biol., San Diego, CA 12, 657-671.

Ilgen, D. R. (1971). Satisfaction with performance as a function of the initial level of expectation and the deviation from expectation. Organizational Behavior and Human Performance, 6(January), 345-361.

Jackson, B. B. (1985). Build customer relationships that last. Harvard Business Review, November/December: 120-128.

Jacoby, J., \& Kyner, D. B. (1973). Brand loyalty vs. repeat purchasing behavior. Journal of Marketing Research, 10(February), 1-9.

Jacoby, J. C., Robert, W., \& William, A. F. (1978). A behavioral process approach to information acquisition in nondurable purchasing. Journal of Marketing Research, 15, 532-544.

Johnson, M. D., \& Fornell, C. (1991). A framework for comparing customer satisfaction across individuals and product categories. Journal of Economic Psychology, 12, 267-286. 
Jones, M. A., Mothersbaugh, D. L., \& Betty, S. E. (2000). Switching barriers and repurchase intentions in services. Journal of Retailing, 76(2),259- 272.

Jones, M. A., Mothersbaugh, D. L., \& Betty, S. E. (2002). Why customers stay: Measuring the underlying dimensions of services switching costs and managing their differential strategic outcomes. Journal of Business Research, 55, 441-450.

Jun, X., \& Bin, L. (2005). An empirical study of customer loyalty of the telecommunication industry in China. ICEC'05, August, 15-17.

Kahneman, D., \& Tversky, A. (1979). Prospect theory: An analysis of decision under risk. Econometrica, 47, 263-291.

Keller, K. (1993). Conceptualizing, measuring, and managing customer basedequity. Journal of Marketing, 1.

Kim, M. K., Park, M. C., \& Jeong, D. H. (2004). The effects of customer satisfaction and switching barrier on customer loyalty in Korean mobile telecommunication services. Telecommunications Policy, 28(1), 45-59.

Klemperer, P. (1987). Markets with consumer switching costs. The Quarterly Journal of Economics, 10(23), 76-94.

Klemperer, P. (1995). Competition when consumers have switching costs: An overview with applications to industrial organization, macroeconomics and international trade. Review of Economic Studies, 62(5), 15-39. EJM 39,7/8 924.

Kotler, P. (1997). Marketing management: Analysis, planning, implementation and control (9th ed.). Upper Saddle River, NJ: Prentice Hall.

Kristensen, K., Gronholdt, L., \& Martensen, A. (2000). Customer satisfaction measurement at Post Denmark: Results of application of the European customer satisfaction index methodology. Total Quality Management, 11(7), 1007-15.

Lacobucci, D., Grayson, K. A., \& Ostrom, A. L. (1994). The calculus of service quality and customer satisfaction. In T. A. Swartz, D. E. Bowen, \& S. W. Brown (Eds.), Advances in Services Marketing and Management, 3,1-67. Greenwich, CT: JAI.

Lacobucci, D., \& Ostrom, A. (1996a). Commercial and interpersonal relationships: Using the structure of interpersonal relationships to understand individual-to-individual, individual-to- firm, and finn-to-firm relationships in commerce. International Journal of Research in Marketing, 13(1), 53-72.

Lee, M., \& Cunningham, L. F. (2001). A cost/benefit approach to understanding service loyalty. Journal of Services Marketing, 15(2), 113-130.

62 IJMS 18 (2), 43-66 (2011) 
Liang, C., Kraemer K. H., Morris, A., Schiffmann, R., Price V. H., Menefee, E. et al. (2005). Characterization of tiger tail banding and hair shaft abnormalities in trichothiodystrophy. J Am Acad Dermatol, 52, 224-232

Liljander, V., \& Tore, S. (1993). Emotions in service satisfaction. International Journal of Service Industry Management, 8(2), 148-169.

Liljander, V., Strandvik, T. (1993a). Estimating zones of tolerance in perceived service quality. International Journal of Service Industry Management, 4(2), 6-28.

MacInnis, D. J., \& Price, L. L. (1987). The role of imagery in information processing: Preview and extensions. Journal of Consumer Research, 13(4), 73-91.

Magnus, S. (2005). Measuring customer loyalty with multi-item scales: A case for caution. International Journal of Service Industry Management, 17(1), 76-98.

Mak, B. L., \& Sockel, H. (2001). A confirmatory factor analysis of IS employee motivation and retention. Information and Management, 38, 265-76.

Manish, M. (2001). Customer loyalty solutions, interactive. Retrieved from http://www.brandchannel.com

Markus, H. (1977). Self-schemata and processing information about the self. Journal of Personality and Social Psychology, 35, 63-78.

Moan, K. K., Myeong, C. P., \& Dong, H. J. (2004). The effects of customer satisfaction and switching barrier on customer loyalty in Korean mobile telecommunication services. Telecommunications Policy, 28,145-159.

Mohr, L. B. (1990). Understanding significance tests. Newbury Park, CA: Sage Publications.

Nelson, O., Ndubisi, Naresh K. Malhotra., \& Chan Kok Wah. (2007). Relationship marketing, customer satisfaction and loyalty: A theoretical and empirical analysis from an Asian perspective. Journal of International Consumer Marketing, 21, 5-16.

Nunnally, J. C. (1967). Psycometric theory. New York: McGraw-Hill.

Nunnally, J. C. (1978). Psychometric theory (2nd ed.). New York: McGraw-Hill.

Odin, Y., Odin, N., \& Florence, P.V. (2001). Conceptual and operational aspects of brand loyalty an empirical investigation. Journal of Business Research, 53, 75-84.

Oh, H. (1999). Service quality, customer satisfaction, and customer value: A holistic perspective. International Journal of Hospitality Management, 18, 67-82.

Oh, H. C. (1995). An empirical study of the relationship between restaurant image and customer loyalty (Unpublished doctoral dissertation). Virginia Polytechnic Institute and State University. 
Oliver, R., \& Linda, G. (1981). Effects of satisfaction and its antecedents on consumer preferences and intention. Advances in Consumer Research, 8, 88-93.

Oliver, R. L. (1980). A cognitive model of the antecedence and consequences ofsatisfaction decisions. Journal of Marketing Research, 17(September), 46-49.

Oliver, R. L., \& DeSarbo, W. S. (1988). Response determinants in satisfaction judgement. Journal of Consumer Research, 14(March), 495-507.

Oliver, R. L. (1980). A cognitive model of the antecedents and consequences of satisfaction decisions. Journal of Marketing Research, 17(4), 462.

Oliver, R. L. (1999). Whence consumer loyalty? (Special Edition). Journal of Marketing, 63(5), 33-44.

Palmer, A. (1998). Principles of service marketing (2nd ed.). New York: McGraw-Hill.

Parasuraman, A., Berry, L. L., \& Zeithami, V. A. (1991). Refinement and reassessment of the SERVQUAL Scale. Journal of Retailing, 67(4), 420-450.

Parasuraman, A., Zeithamal, V. A., \& Berry, L. L. (1988). SERVQUAL: A multiple-item scale for measuring consumer perceptions of service quality. Journal of Retailing, 64, 12-40.

Pieters, R., \& Bottschen, G. (1999). Special issue on service marketing and management: European contributions. Journal of Business Research, 44(1), 1-4.

Ringham, L. A., Johnson, L. W., \& Morton. C. P. (1994). Customer satisfaction and loyalty for a continuous consumer service. Australasian Journal of Market Research, 2(2), 43-48.

Reicheled, F., \& Sasser, W. E. (1990). Zero defections: Quality comes to services. Harvard Business Review, 68(September-October), $105-111$.

Ross, S. (2002). Making the rewards fit the degree of customer loyalty. Ne Media Age, 1, 19

Rust, R. T., \& Zahorik, A. J. (1993). Customer satisfaction, customer retention, and market share. Journal of Retailing, 69(2), 193-215.

Sekaran, U. (1992). Research methods for business. New York: John Wiley \& Sons.

Serkan, A., \& Go"khan, O. (2004). The analysis of antecedents of customer loyalty in the Turkish mobile telecommunication market. European Journal of Marketing, 39(7/8), 910-925

Shankar, V., Amy, K. S., \& Arvind, R. (2003). Customer satisfaction and loyalty in online and offline environments. International Journal of Research in Marketing, 20, 153-175.

64 IJMS 18 (2), 43-66 (2011) 
Sharma, N., \& Patterson, P. G. (2000). Switching costs, alternative attractiveness and experience as moderators of relationship commitment in profesional consumer services. International Journal of Service Industry Management, 11(5), 470-90.

Shy, O. (2002). A quick and easy method for estimating switching costs. International Journal of Industrial Organization, 20, 71-87.

Simon, J. L. (1974). Interpersonal welfare comparison can be made and used for redistribution decisions. Kyklos, 27, 68-98.

Taylor, S. (1994). Waiting for service: The relationship between delays and evaluations of service. Journal of Marketing, 58(April), 56-69.

Tor, W. A., \& Bodil, L. (1997). Customer loyalty and complex services. The impact of corporate image on quality, customer satisfaction and loyalty for customers with varying degrees of service expertise. International Journal of Service Industry Management, 9(1), 7-23.

Van Raaij, W. F. (1981). Economic phsycology. Journal of Economic Phsycology, 1(1), 1-24.

Vandamme, R., \& Leunis, J. (1993). Development of a multiple-item scale for measuring hospital service quality. International Journal of Service Industry Management, 4(3), 30-49.

Wong, A., \& Sohal, A. (2002). An examination of the relationship between trust, commitment and relationship quality. International Journal of Retail \& Distribution Management, 30(1), 34-50.

Wong, A., \& Sohal, A. (2003). Examining the service quality-customer loyalty relationship: Differences between city and country retail districts. International Journal - Marketing Intelligence Planning, 21(5) , 292-304.

Weekes, D. J., Scott, M. E., \& Tidwell, P. M. (1996). Measuring quality and client satisfaction in professional business services. Journal of Profesional Services Marketing, 14(2), 25-45.

Weiner, B. (1985). An attributional theory of achievement motivation and emotion. Psychological Review, 92(October), 548-573.

Yi, Y. (1990). A critical review of consumer satisfaction. Review of marketing. In V. Zeithaml (Ed.), American Marketing Association (pp. 68-123). Chicago.

Yuille, J. C., \& Catchpole, M. J. (1977). The role of imagery in models of cognition. Journal of Mental Imagery, 1, 171-80.

Zeithaml, V. A. (1988). Consumer perceptions of price, quality, and value: A means-end model and synthesis of evidence. Journal of Marketing, 52(July), 2-22. 
Zhijian, H., Xu, X., \& H. Li, S. (2005). Services systems and services management. Proceedings of ICSSSM '05. International Conference, 5(2).

Zoe, S. D. (2005). Customer satisfaction, loyalty and commitment in service organizations some evidence from Greece. Management Research News, 29(12), 782-800.

66 IJMS 18 (2), 43-66 (2011) 